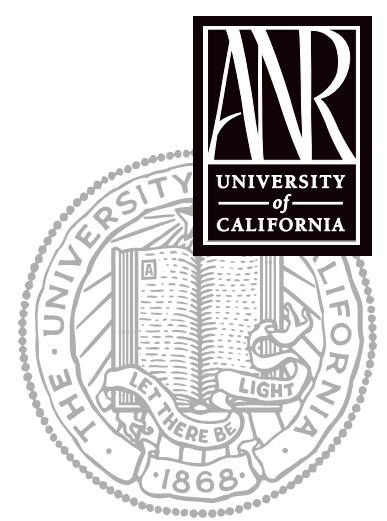

UNIVERSITY OF CALIFORNIA

Division of Agriculture and Natural Resources http://anrcatalog.ucdavis.edu

\title{
Methods to Enable the Coexistence of Diverse Corn Production Systems
}

KENT BRITTAN, University of California Cooperative Extension Farm Advisor, Yolo County

Corn (Zea mays) is produced throughout California as fresh sweet corn, silage corn, and grain. In 2005, California produced 25,000 acres (10,100 ha) of sweet corn, 440,000 acres $(178,000 \mathrm{ha})$ of silage corn, and 100,000 acres (40,500 ha) of grain. The worth of each was $\$ 109$ million, $\$ 300$ million, and $\$ 52$ million, respectively, for an annual total state value of $\$ 500$ million (NASS 2006). People consume approximately $18 \%$ of the total corn produced in California, with the rest being eaten by animals, mainly dairy cows. California is a net importer of corn, with much of this additional grain coming from the midwestern states to feed animals in large poultry houses, cattle feedlots, and to be used in flour mills.

\section{Does cross-pollination occur in corn?}

Unlike all other major grain crops such as wheat, rice, and barley, the corn plant has separate male and female flowering parts. The tassel and the ear are the male and female flowering structures, respectively. During the flowering stage, pollen shed and silking are necessary aspects of generating the next generation of seeds. Because of the separation of the male and female parts, cross-pollination of corn plants occurs with high frequencies. Under field conditions, $97 \%$ or more of the kernels produced by each plant are pollinated by other plants.

Cross-pollination is achieved by wind and gravity dispersal of the shedding pollen. Pollen is light and can be carried considerable distances by the wind. However, most of pollen settles within 20 to 50 feet $(6$ to $15 \mathrm{~m})$ of the donor plant. Under favorable conditions, pollen is only viable for 18 to 24 hours, with viability diminishing rapidly from desiccation. Over a 7- to 21-day period, tassels at the top of the plant produce 2 to 5 million pollen grains from the anthers. This translates into 2,000 to 5,000 pollen grains shed for each silk that connects to a single ovule. Pollen shed from the top of the plant facilitates dispersal. Corn pollen (among the largest and heaviest of the angiosperms, the group of plants that produces flowers, fruit, and seed), is approximately 100 microns, compared to most other wind-pollinated plants that have pollen ranging from 17 to 58 microns (Stanley and Linskens 1974).

Pollen drift, which can result in the passage of genes from one corn variety to another, is not limited to genetically engineered (GE) traits and has become an important consideration in non-GE and organic corn production. Producers are concerned that pollen drift from GE hybrids to nearby non-GE varieties will contaminate their corn by cross-pollination. Farmers growing GE hybrids approved for export, as well as those growing non-GE varieties, want to avoid contamination of their crops by the GE corn that has not yet received approval for overseas markets (Nielsen 2003a). Labeling tolerances of major import markets for non-GE corn are: European Union, 0.9\%; Japan, 5\%; and Mexico, 5\%. If the shipment exceeds these levels it must be labeled "May Contain" GE material.

\section{How far does corn pollen travel?}

Dispersal of corn pollen has been intensively studied. Some studies measured the 
others have measured the degree of outcrossing in neighboring corn. The latter approach is probably more meaningful in assessing the impact of pollen drift from GE cornfields. Once released from the tassels into the air, pollen grains can travel as far as $1 / 2$ mile (800 $\mathrm{m})$ in 2 minutes in a wind of 15 miles per hour $(27 \mathrm{~km} / \mathrm{h}$ ) (Nielsen 2003b). However, most pollen from a cornfield is deposited within a short distance of the corn plant. Past studies have shown that, at a distance of 200 feet $(60 \mathrm{~m})$ from the source of pollen, the concentration averages only about $1 \%$, compared with pollen samples collected about 3 feet $(0.9 \mathrm{~m})$ from the pollen source (Burris 2002). The number of outcrosses is reduced to one-half at a distance of 12 feet $(3.6 \mathrm{~m})$ from the pollen source, and at a distance of 40 to 50 feet (12 to $15 \mathrm{~m}$ ), the number of outcrosses is reduced by $99 \%$. Thomison (2004) showed cross-pollination between cornfields could be limited to $1 \%$ or less by a separation distance of 660 feet $(200 \mathrm{~m})$, and to $0.5 \%$ or less by a separation distance of 984 feet (300 m). However, cross-pollination frequencies could not be reduced to $0.1 \%$ consistently, even with isolation distances of 1,640 feet $(500 \mathrm{~m})$. Currently, the Association Official Seed Certification Agency (AOSCA) has set isolation standards with border row requirements during production of hybrid maize seed (table 1). Over the past 30 years,

Table 1. Minimum border rows of isolation for hybrid corn production (AOSCA standards)

\begin{tabular}{|c|c|c|}
\hline \multirow{2}{*}{$\begin{array}{l}\text { Minimum distance from } \\
\text { contaminant (ft) }\end{array}$} & \multicolumn{2}{|c|}{ Number of rows of isolation per field size } \\
\cline { 2 - 3 } & Up to $\mathbf{2 0}$ ac & $\mathbf{2 0}$ ac \\
\hline 410 & 0 & 1 \\
\hline 370 & 2 & 2 \\
\hline 330 & 4 & 3 \\
\hline 290 & 6 & 4 \\
\hline 245 & 8 & 5 \\
\hline 205 & 10 & 6 \\
\hline 165 & 12 & 7 \\
\hline 125 & 14 & 8 \\
\hline 85 & 16 & 10 \\
\hline 0 & not permitted & \\
\hline
\end{tabular}

these standards have been useful when genetic purity was defined by morphological phenotypes and 95 to $98 \%$ purity was satisfactory (Burris 2000).

Several studies have been performed to evaluate the impact of pollen drift from fields containing GE corn to neighboring non-GE cornfields. A Colorado study (Byrne et al. 2003) tracked the drift of pollen from blue corn and GE Roundup Ready corn into adjacent conventional corn. Corn with the marker traits (blue kernels or Roundup herbicide tolerance) was planted adjacent to corn without those traits. Cross-pollination was greatest at the closest sampling site, up to $46 \%$ outcrossing at a distance of about 3 feet $(1 \mathrm{~m})$ from the edge of the test plots. Cross-pollination dropped rapidly, with only $0.23 \%$ cross-pollinated blue kernels when a 150 -foot (46-m) border separated the plots. With the Roundup Ready plot, $0.75 \%$ of the corn showed cross-pollination at 150 feet, with the greatest distance for any detected cross-pollination 600 feet $(182 \mathrm{~m})$. These results suggest that $150 \mathrm{feet}$ is a reasonable isolation distance between GE and non-GE corn to limit cross-pollination to less than $1 \%$.

W. Eberhard Weber, leader of the research team and head of the Department of Plant Breeding and Plant Protection at Martin-Luther-University at Halle-Wittenberg, Germany, was cited as saying that his study, which measured GM contamination in corn harvested from surrounding non-GM fields, shows that non-GM corn planted at least 60 feet $(20 \mathrm{~m})$ from GM corn was not contaminated above the EU-allowed limit of $0.9 \%$ (Stafford 2004). In follow-up research in 2005 the recommended distance of 60 feet $(20 \mathrm{~m})$ was shifted due to winder conditions to 150 feet $(50 \mathrm{~m})$ of lower-growing non-corn crops or 75 feet $(25 \mathrm{~m})$ of an adjacent non-GE corn pollen barrier.

\section{Are more stringent limits on gene transfer desired?}

Diverse cropping systems in California have put limits on the movement of undesirable gene transfer. Popcorn and hybrid super-sweet sweet corn have traditionally required isolation to avoid unwanted phenotypic variation. Now U.S. Federal policy developed for organic farmers states that GE crops cannot be designated as organic (NOP 2006 ). Therefore, although genes have moved from conventional to organic crops for years, 
movement of engineered genes from conventionally grown GE crops to organic crops can cause problems for organic farmers. For this reason, several state seed certification agencies that offer Identity Preserved (IP) grain programs for corn require that non-GE identity preserved corn be planted at least 660 feet $(200 \mathrm{~m})$ from any GE corn varieties. (Thomison 2004). This 660-foot distance is based on established testing by the Association of Official Seed Certifying Agencies and is four times the distance recommended by research in the European Union (AOSCA 1984). Isolation distance requirements can be modified by adding varying numbers of non-GE border rows (see below), with the number determined by the acreage of the non-GE IP corn. The border rows keep the non-GE field from being "flooded" with non-GE pollen by trapping adventitious pollen from the GE variety. Corn from the border rows is removed and destroyed, or sold as a noncertified product in the case of organic sweet corn.

Recommendations have been suggested that might be used for California organic corn production (Thomison 2004):

- For corn fields over 20 acres ( $8 \mathrm{ha}$ ), if the actual isolation distance (a required 660 feet, or $200 \mathrm{~m}$ ) is less than 165 feet $(50 \mathrm{~m})$, the protocol can be modified by the postpollination removal of 16 border rows, or 40 feet $(12 \mathrm{~m})$ of corn.

- For corn fields over 20 acres ( $8 \mathrm{ha}$ ), if the actual isolation distance is between 165 and 660 feet ( 50 and $200 \mathrm{~m}$ ), the protocol can be modified by the postpollination removal of 8 border rows.

- For corn fields over 20 acres ( 8 ha) with an isolation distance greater that 660 feet $(200 \mathrm{~m})$, border rows are not necessary but are advisable.

These isolation and border row requirements are designed to produce corn grain that is not more than $0.5 \%$ contaminated with GE traits (Burris 2000; Thomison 2004). European Union research indicates that these requirements are more stringent than their current results, but our more diverse corn production and winder conditions support these requirements.

\section{What practices can be used to reduce pollen flow from corn?}

A number of practices can be adopted by farmers to reduce the likelihood that undesirable pollen flow will occur from one field to another.

\section{Use isolation and border rows}

Special isolation or separation is one of the most effective methods for reducing pollen contamination. The California Crop Improvement Association (CCIA) has no published guidelines on isolation distances for corn. However, it uses the Nebraska Seed Association (NSA) hybrid corn seed production isolation requirement of 660 feet $(200 \mathrm{~m})$ without border rows for the few acres of hybrid corn seed produced in the state. Border rows, or pollen barriers, consists of plants planted around the source or recipient field. If the outer rows of the recipient field function as a barrier, the isolation distance could decrease. Border rows of corn can reduce cross-fertilization levels more effectively than an isolation distance of the same length (Mele 2005).

\section{Know what corn is growing near you}

Be aware of the kinds of corn that are being grown around your corn acreage. Both before and after you plant, locate all possible corn pollen sources within $1 / 2$ mile $(805 \mathrm{~m})$. Also, prevailing wind directions with regard to your corn and neighboring GE corn are critical to control potential pollen flow. Communicate with all parties who might be affected by your GE corn crop, including smaller growers. This situation is no different than other hybrid seed crops that require isolation. Volunteer corn plants from no-till, minimum till, or continuous corn production areas can also be sources of unwanted pollen, and it is important to manage these populations. 


\section{Stagger planting dates and hybrid maturity times}

Use different planting dates and varying hybrid maturity times to reduce cross-pollination between fields of GE and non-GE corn. For example, planting short-season non-GE corn hybrids followed by full-season GE hybrids reduces the chance for pollen contamination from the field with the GE variety to the earlier-planted, earlier-maturity non-GE hybrid in adjacent fields. However, there are shortcomings to this approach. Differences in maturity between the early- and late-hybrids may not be great enough to ensure that the flowering periods of the hybrids will not overlap, especially when climatic conditions accelerate or delay flowering. Moreover, this strategy only works if you control adjacent fields or closely coordinate corn planting with those around you. This approach is also problematic for sweet corn growers who plant only a few rows every 2 weeks all season long.

\section{Keep good records and know the regulations}

Record your seed sources and where and when seed was planted. Read and understand germplasm licensing agreements issued by the seed companies. Retain copies of all agreements that you sign and keep thorough, well-organized records. If you are producing certified organic corn under contract, understand what requirements you need to meet to fulfill the contract obligations and what isolation distances you will need to maintain the purity specified in the agreement. Know where to store the crop and how it will be transported in order to maintain certification.

\section{PERSPECTIVE}

California has over 565,000 acres (228,000 ha) of corn in production annually in a very diverse and fluid agricultural environment. It will take everyone communicating and working together and using the best information available to control pollen flow so all farmers can achieve their production goals.

\section{REFERENCES}

AOSCA (Association of Official Seed Certifying Agencies). 1984. Certification handbook. Publication 23. Raleigh, NC: AOSCA.

Burris, J. 2000. Recommendations for producing non-GMO corn and soybeans: A plan for year 2000. Purdue University Chat 'n Chew Café Web site, http://www.agry.purdue.edu/ext/corn/news/articles.00/GMO_Issues-000309.html.

- 2002. Adventitious pollen intrusion into hybrid maize seed production fields. American Seed Trade Association Web site, http://www.amseed.com/govt_ statementsDetail.asp?id=69.

Byrne, P. F., K. A. Terpstra, T. A. Dabbert, and R. Alexander. 2003. Estimating pollenmediated flow in corn under Colorado conditions. Annual Meetings Abstracts (CD-ROM). Madison, WI: American Society of Agronomy, Crop Science Society of America, and Soil Science Society of America.

Mele, E., G. Penas, J. Serra, J. Salvia, J, Ballester, M. Bas, M. Palaudelmas, and J. Messeguer. 2005. Quantification of pollen gene flow in large maize fields by using kernel color trait. In A. Messean, ed., Proceedings of the 2nd international conference on co-existence between GM and non-GM based agricultural supply chains. Montpellier, France: Agropolis Museum Productions. 289-291.

NASS (National Agricultural Statistics Service). 2006. Statistics by subject. NASS Web site, http://www.usda.gov/nass/.

Nielsen, R. L. 2003a. Corn segregation: A necessary evil in today's biotech age? Purdue University Corny News Network Web site, http://www.agry.purdue.edu/ ext/corn/news/articles.03/GMO_Segregation-0423.html. 
2003b. Sex in the corn field: Tassel emergence and pollen shed. Purdue University Corny News Network Web site, http://www.agry.purdue.edu/ext/corn/ news/articles.03/Tassels-0716.html.

NOP (National Organic Program). 2006. Organic Foods Production Act of 1990. NOP Web site, http://www.ams.usda.gov/nop/archive/OFPA.html.

Stafford, N. 2004. German GM study complete. The Scientist 5(1): $20041124-$ 04. Available at The Scientist Web site, http://www.biomedcentral.com/ news/20041124/04.

Stanley, R. G., and H. F. Linskens. 1974. Pollen biology, biochemistry and management. New York: Springer-Verlag.

Thomison, P. 2004. Managing "pollen drift" to minimize contamination of nonGMO Corn. AGF-153. Ohio State University Extension Fact Sheet Web site, http://ohioline.osu.edu/agf-fact/0153.html.

To order or obtain printed ANR publications and other products, visit the ANR Communication Services online catalog at http://anrcatalog.ucdavis.edu. You can also place orders by mail, phone, or FAX, or request a printed catalog of our products from:

University of California

Agriculture and Natural Resources

Communication Services

6701 San Pablo Avenue, 2nd Floor

Oakland, California 94608-1239

Telephone: (800) 994-8849 or (510) 642-2431

FAX: (510) 643-5470

E-mail inquiries: danrcs@ucdavis.edu

An electronic version of this publication is available on the ANR Communication Services Web site at http://anrcatalog.ucdavis.edu.

Publication 8192

ISBN-13: 978-1-60107-385-3

ISBN-10: 1-60107-385-2

(C) 2006 by the Regents of the University of California, Division of Agriculture and Natural Resources. All rights reserved.

The University of California prohibits discrimination or harassment of any person on the basis of race, color, national origin, religion, sex, gender identity, pregnancy (including childbirth, and medical conditions related to pregnancy or childbirth), physical or mental disability, medical condition (cancer-related or genetic characteristics), ancestry, marital status, age, sexual orientation, citizenship, or status as a covered veteran (covered veterans are special disabled veterans, recently separated veterans, Vietnam era veterans, or any other veterans who served on active duty during a war or in a campaign or expedition for which a campaign badge has been authorized) in any of its programs or activities. University policy is intended to be consistent with the provisions of applicable State and Federal laws.

Inquiries regarding the University's nondiscrimination policies may be directed to the Affirmative Action/Staff Personnel Services Director, University of California, Agriculture and Natural Resources, 1111 Franklin Street, 6th Floor, Oakland, CA 94607-5201 (510) 987-0096. For a free catalog of other publications, call (800) 994-8849. For help downloading this publication, call (530) 754-5112.

To simplify information, trade names of products have been used. No endorsement of named or illustrated products is intended, nor is criticism implied of similar products that are not mentioned or illustrated.

This publication has been anonymously peer reviewed for technical accuracy by University of California scientists and other qualified professionals. This review process was managed by the ANR Associate Editor for Agronomy and Range Sciences.

$\mathrm{pr}-11 / 06-\mathrm{SB} / \mathrm{CM}$ 